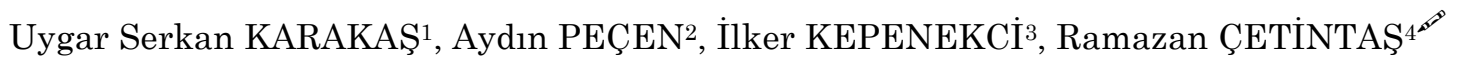 \\ ${ }^{1}$ Plant Protection Research Institute, Diyarbakır, 21110, Turkey, ${ }^{3}$ Tokat Gaziosmanpasa University, Faculty of Agriculture, Department of \\ Plant Protection, Tokat, 60240, Turkey, ${ }^{4}$ Kahramanmaras Sutcu Imam University, Faculty of Agriculture, Department of Plant Protection, \\ Kahramanmaras, 46040, Turkey \\ ${ }^{1}$ https://orcid.org/0000-0003-4144-5682, ${ }^{2}$ https://orcid.org/0000-0001-6072-6581, ${ }^{3}$ https://orcid.org/0000-0002-5738-6915 \\ ${ }^{4}$ https://orcid.org/0000-0002-0506-6645 \\ $\triangle$ : cetintas@ksu.edu.tr
}

\begin{abstract}
Plant parasitic nematodes (PPNs) are the leading source of damage to crops in agricultural production and they can cause very serious yield reductions. The Tylenchida (Nematoda) constitutes the most important group of PPNs due to containing a large number of economically important plant parasitic species. This study was conducted in apple (Pyrus malus L.) and walnut (Juglans regia L.) orchards in Bingöl (Turkey) between 2016 and 2017. For this purpose, total of $52 \mathrm{soil} /$ root samples were taken from $20-40 \mathrm{~cm}$ depth of related areas during summer months. In laboratory, active PPNs were extracted from soil and roots parts by modified Baermann Funnel method. Obtained nematodes were killed at $60^{\circ} \mathrm{C}$, fixed in TAF in mounted slides. PPNs belonging to Tylenchida were identified morphometrically and morphologically under the light microscope. As result of the study; eighteen PPN species were determined and classified under the Tylenchida order as three suborders, three superfamilies, four families and seven genera in the apple and walnut growing areas. The most encountered PPN species in this study were Filenchus filiformis, Helicotylenchus canadiensis, $H$. digonicus, $H$. vulgaris, Pratylenchoides alkani and Psilenchus hilarulus. All species were determined for the first time in the nematoda fauna of Bingöl province in apple and walnut orchards.
\end{abstract}

\section{Research Article}

$\begin{array}{ll}\text { Article History } & \\ \text { Received } & : 10.06 .2020 \\ \text { Accepted } & : 27.07 .2020\end{array}$

Keywords
Plant parasitic nematodes
Bingöl
Apple
Walnut
Tylenchida

\title{
Bingöl İli Elma (Pyrus malus L.) ve Ceviz (Juglans regia L.) Bahçelerinde Bitki Paraziti Nematod Türlerinin Belirlenmesi
}

\section{ÖZET}

Bitki paraziti nematodlar (BPN'ler), tarımsal ürünlerde önemli zarar oluşturmakta ve çok ciddi verim kayıplarına neden olabilmektedirler. Tylenchida (Nematoda) takımı ekonomik açıdan önemli çok sayıda bitki paraziti nematod türünü barındırdığından en önemli BPN grubunu oluşturmaktadır. Bu çalışma 2016-2017 yılları arasında Bingöl (Türkiye) ili elma (Pyrus malus L.) ve ceviz (Juglans regia L.) bahçelerinde yürütülmüştür. $\mathrm{Bu}$ amaçla, yaz aylarında ilgili alanlardan 20-40 cm derinlikten toplam 52 toprak/kök örneği alınmıştır. Laboratuvarda, Geliştirilmiş Baermann Huni yöntemi ile toprak ve kök kısımlarından aktif BPN'ler ekstrakte edilmiştir. Elde edilen nematodlar $60^{\circ} \mathrm{C}$ 'de öldürüldükten sonra TAF çözeltisinde fikse edilerek lam üzerinde sabitleştirilmiştir. Tylenchida takımına ait BPN'ler, ışık mikroskobu altında morfometrik ve morfolojik olarak tanımlanmıştır. Çalışma sonucunda; elma ve ceviz yetiştiriciliği yapılan alanlarda $18 \mathrm{BPN}$ türü belirlenmiş ve bu türler Tylenchida takımı altında üç alttakım, üç üstfamilya, dört familya ve yedi cins olarak sınıflandırılmıştır. Bu çalışmada Filenchus filiformis, Helicotylenchus canadiensis, $H$. digonicus, $H$. vulgaris, Pratylenchoides alkani ve Psilenchus hilarulus en çok tespit edilen

\section{Araştırma Makalesi}

Makale Tarihçesi

Geliş Tarihi : 10.06 .2020

Kabul Tarihi : 27.07.2020

\author{
Anahtar Kelimeler \\ Bitki Paraziti Nematodları \\ Bingöl \\ Elma \\ Ceviz \\ Tylenchida
}


BPN türleri olmuştur. Tüm türler Bingöl ilindeki elma ve ceviz bahçeleri nematod faunasında ilk kez belirlenmiştir.

To Cite : Karakaş US, Peçen A, Kepenekçi İ, Çetintaş R 2021. Determination of Plant Parasitic Nematode Species of Tylenchida (Nematoda) in Apple (Pyrus malus L.) and Walnut (Juglans regia L.) Orchards in Bingöl Province of Turkey. KSÜ Tarım ve Doğa Derg 24 (3): 554-560. https://doi.org/10.18016/ksutarimdoga.vi.750286.

\section{INTRODUCTION}

Turkey, due to its geographical location, has a very favorable climate for all fruits excluding some tropical plants. In this regard, Turkey, the origin of horticultural production, is the main homeland of many fruit species in the world (Ağaoğlu et al., 1997). A significant portion of fruit species being grown in Turkey is temperate zone fruits. Among these, grape, apple, hazelnut, pear, peach, apricot, plum, cherry, walnut, chestnut, quince, almond, pistachios are widely grown crops. Apple (Pyrus malus L.) is one of the fruits grown in almost every climatic region of this country. The annual apple production of Turkey is approximately 3.6 million ton. Apple cultivation has been concentrated in all provinces of the country recently. Walnut (Juglans regia L.) is the oldest cultivated fruits in the world grown spontaneously almost all across of the country (Sen, 1986). The annual walnut production of Turkey is approximately 225 thousand ton. Plant parasitic nematodes (PPNs) are the leading cause of damage to crops, and although actual size of the their damage to agriculture is too difficult to assess, they are able to cause a very serious reductions in crop yield. Nematodes can be primer pathogens by direct attacking plants or can be seconder parasites by creating the entrance to the other many soil-borne pathogens. The Tylenchida (Nematoda) constitutes of the most important group of PPNs due to its host range of economically important crops. There are various studies about PPN-host association and distribution in different localities of Turkey. A total of 240 PPNs belonging to 56 genera of Tylenchida were detected from 66 different host plants in 48 different localities of the country by second half of 2014 (Kepenekci, 2014). Pest and pathogen management are fairly important for the country's agriculture. Increasing agricultural production per unit are becoming even more vital due to the rapid population increase in Turkey. Within this perspective, the crops including apple and walnuts need to be protected from pests and pathogens including PPNs. Therefore, species of PPN species need to be identified correctly in order to develop effective management strategies. There is only one study available about identification of PPN species in forage areas in Bingöl (Yıldız et al., 2012). There is no any other study of PPN species in any crops in this province. Therefore, the aim of this study was to determine PPN species causing economic losses in apple and walnut orchard areas in Bingöl province.

\section{MATERIAL and METHOD}

A total of 52 soil-root samples were taken from apple and walnut orchards of Bingöl (Turkey) and its surroundings (Adaklı, Genç, Karlıova, Kiğı̆, Solhan, Yayladere) to determine PPN species. The samples were collected incidentally to represent the whole region. Samples were usually taken from orchards possessing five years or older trees. Each orchard was considered as one unit and samples were taken from five different spots of the same tree from a depth of 20 $40 \mathrm{~cm}$. The soil and root samples of each tree was collected into a polyethylene bag and labelled.

\section{Laboratory studies}

\section{Constitution of permanent preparations of nematodes}

A petri method, Modified Baermann Funnel Method, was used to extract free and mobile PPNs from the soil (Barker, 1985; Southey, 1986). In order to identify nematodes at the species level, constitution of permanent preparations processes were followed based on common preparation methods. For this purpose, nematodes precipitated in the centrifuge tubes were kept for 2 minutes in hot water bath at $60^{\circ} \mathrm{C}$. The dead nematodes were fixed in TAF solution $(7 \mathrm{ml}$ formalin (40\% formaldehyde) $+2 \mathrm{ml}$ triethanolamine $+91 \mathrm{ml}$ distilled water) (Hooper, 1986) and kept in solution I (1 part of glycerin and 79 parts of distilled water) and solution II (5 parts glycerin and 95 parts (96\%) ethanol) (Seinhorst, 1959). In this way, the nematodes, taken in pure glycerin, were separated according to their genus and taken on the slide prepared by WaxRing method (Hooper, 1986). The nematodes later were fixed on the heater with coverslip and made ready for the diagnosis.

\section{Identification of nematodes}

PPNs were identified at the species level by morphological and morphometric characteristics. Synonyms, systematic position and phylogenetic classification of Tylenchid nematodes were determined by following Siddiqi (2000).

\section{RESULTS and DISCUSSION}

In this study, PPN species belong to the genera of Coslenchus Siddiqi (Tylenchida: Tylenchidae), Filenchus Andrassy (Tylenchida: Tylenchidae), Helicotylenchus Steiner (Tylenchida: Hoplolaimidae), Pratylenchoides Winslow (Tylenchida: Pratylenchidae), Pratylenchus Filipjev (Tylenchida: Pratylenchidae), Psilenchus DeMan (Tylenchida: 
Belonolaimidae) and Trophurus Loof (Tylenchida: Belonolaimidae) were identified. PPN species determined in the survey are shown in Table 1. Among the species found, six PPN species were determined from apple orchards and classified in the Tylenchida order, three suborders, two superfamilies, three families and in five genera. These species were Coslenchus turkeyensis Siddiqi; Filenchus cylindricauda $\mathrm{Wu}, \quad$ Siddiqi; Helicotylenchus canadiensis Waseem; H. digonicus Perry, in Perry, Darling \& Thorne; Pratylenchoides alkani Yüksel; Psilenchus hilarulus De Man. Among the species found, sixteen PPN species were determined in the walnut orchards and classified under the Tylenchida order as three suborders, three superfamilies, four families and six genera. These species were $F$. filiformis (Bütschli) Meyl; $H$. canadiensis; $H$. crenecauda Sher; $H$. digonicus; H. striatus Firoza \& Maqbool; $H$. tunisiensis Siddiqi; $H$. vulgaris Yuen; $P$. alkani; $P$. camachoi Barcina, Castillo \& Pais; $P$. erzurumensis Yüksel; $P$. leiocauda Sher; $P$. ritteri Sher; Pratylenchus penetrans (Cobb) Filipjev \& Schuurmans Stekhoven; P. thornei (Sher \& Allen), (Sher); P. hilarulus and Trophurus sculptus Loof. These species were determined for the first time in the nematoda fauna of apple and walnut orchards in Bingöl province (Turkey). The most encountered PPN species in this study were $F$. filiformis, $H$. canadiensis, $H$. digonicus, $H$. vulgaris, $P$. alkani and $P$. hilarulus.

Çizelge 1. Bingöl ilindeki elma ve ceviz bahçelerinde Tylenchida (Nematoda) takımında tespit edilen bitki paraziti nematod türleri

Table 1. The detected plant parasitic nematode species under the Tylenchida (Nematoda) order in apple and walnut orchards in Bingöl province.

\begin{tabular}{|c|c|c|}
\hline Family & Nematode species & Host \\
\hline Familya & Nematod türleri & Konukçu \\
\hline \multirow[b]{3}{*}{ Tylenchidae } & Coslenchus turkeyensis Siddiqi & apple \\
\hline & Filenchus cylindricauda Wu, Siddiqi & apple \\
\hline & F. filiformis (Bütschli) Meyl & walnut \\
\hline \multirow{6}{*}{ Hoplolaimidae } & Helicotylenchus canadiensis Waseem & apple, walnut \\
\hline & H. crenecauda Sher & walnut \\
\hline & H. digonicus Perry, in Perry, Darling \& Thorne & apple, walnut \\
\hline & H. striatus Firoza \& Maqbool & walnut \\
\hline & H. tunisiensis Siddiqi & walnut \\
\hline & H. vulgaris Yuen & walnut \\
\hline \multirow{7}{*}{ Pratylenchidae } & Pratylenchoides alkani Yüksel & apple, walnut \\
\hline & P. camachoi Barcina, Castillo \& Pais & walnut \\
\hline & P. erzurumensis Yüksel & walnut \\
\hline & P. leiocauda Sher & walnut \\
\hline & $P$. ritteri Sher & walnut \\
\hline & Pratylenchus penetrans (Cobb) Filipjev \& Schuurmans Stekhoven & walnut \\
\hline & P. thornei (Sher \& Allen), (Sher) & walnut \\
\hline \multirow[b]{2}{*}{ Belonolaimidae } & Psilenchus hilarulus DeMan & apple, walnut \\
\hline & Trophurus sculptus Loof & walnut \\
\hline
\end{tabular}

In this study, a total of 18 PPN species were found in Bingöl province (Turkey). All species were determined for the first time in the nematoda fauna of apple and walnut orchards in this province. Coslenchus turkeyensis, Filenchus filiformis, Helicotylenchus canadiensis, $H$. digonicus, $H$. tunisiensis, $H$. vulgaris, Pratylenchoides alkani, P. leiocauda, Pratylenchus penetrans and $P$. thornei species were found in apple and walnut orchards of Bingöl province. Related to this study, Evlice and Ökten (2008) identified the same species in pear orchards in Ankara (Turkey). Yüksel (1977) studied on measurements and drawings of taxonomic character of some BPN and he found $P$. alkani and $P$. erzurumensis which were similarly detected in walnut of this current study. Kepenekci and Ökten (1996) studied in Ankara province and they identified plant parasitic nematodes species belonging to Helicotylenchus genus from tomato cultivation areas. In this study, $H$. digonicus and $H$. tunisiensis species detected in apple and walnut orchards were similar. Psilenchus hilarulus and Trophurus sculptus were found in both apple and walnut orchards. Similar to this study, Kepenekci et al. (1998) reported $P$. hilarulus in Balıkesir and Ankara (Turkey), and Kepenekci et al. (1999) reported T. sculptus in Ankara on rice. Kepenekci and Zeki (2002) also reported Helicotylenchus digonicus, Pratylenchoides erzurumensis and Psilenchus iranicus in apple orchards of Isparta and Burdur. In current study, $H$. digonicus and $P$. erzurumensis species were detected in walnut orchards. Helicotylenchus crenacauda and $H$. striatus were found in walnut orchards. Similar to 
in this study, Kepenekci and Ökten (1999) reported that $H$. crenacauda and $H$. striatus were detected in Samsun and Sinop (Turkey) from tobacco growing areas. Kepenekci and Ökten (1998) identified Coslenchus turkeyensis, Filenchus filiformis, $F$. cylindricauda, P. alkani, P. leiocauda in their study in the fields of tomato cultivation which went into rotation with carrots in Beypazarı (Ankara). The nematode species detected in apple and walnut orchards in current study were similar of those of detected in some of other crops of previous studies (Table 2).

Çizelge 2. Türkiye'deki diğer çalışmalarda tespit edilen bu bitki paraziti nematod türlerinin konukçuları Table 2. Hosts of these plant parasitic nematode species detected in other studies in Turkey

\begin{tabular}{|c|c|c|c|c|}
\hline Family & Nematode species & Host & Distribution & Reference \\
\hline Familya & Nematod türleri & Konukçu & Yayılım & Referans \\
\hline \multirow{9}{*}{ Tylenchidae } & \multirow{3}{*}{ Coslenchus turkeyensis } & tomato & Ankara & Kepenekci and Ökten (1997a) \\
\hline & & pear & Ankara & Evlice and Ökten (2008) \\
\hline & & apple & Bingöl & In this study \\
\hline & \multirow{3}{*}{ Filenchus cylindricauda } & tomato & Ankara & Kepenekci and Ökten (1998) \\
\hline & & wheat & Adıyaman & $\begin{array}{l}\text { Kasapoğlu Uludamar et al. } \\
(2018)\end{array}$ \\
\hline & & apple & Bingöl & In this study \\
\hline & \multirow{3}{*}{ F. filiformis } & tomato & Ankara & Kepenekci and Ökten (1998) \\
\hline & & pear & Ankara & Evlice and Ökten (2008) \\
\hline & & walnut & Bingöl & In this study \\
\hline \multirow{27}{*}{$\begin{array}{l}\text { Hoplolaimid } \\
\text { ae }\end{array}$} & \multirow[t]{2}{*}{ Helicotylenchus canadiensis } & pear & Ankara & Evlice and Ökten (2008) \\
\hline & & apple, walnut & Bingöl & In this study \\
\hline & \multirow{4}{*}{ H. crenecauda } & tobacco & Samsun, Sinop & Kepenekci and Ökten (1999) \\
\hline & & lentil & Yozgat & Kepenekci (1999) \\
\hline & & walnut & Zonguldak & Kepenekci (2001) \\
\hline & & walnut & Bingöl & In this study \\
\hline & \multirow{5}{*}{ H. digonicus } & $\begin{array}{l}\text { grapevine, } \\
\text { pistachio }\end{array}$ & Adıyaman & $\begin{array}{l}\text { Kasapoğlu Uludamar et al. } \\
(2018)\end{array}$ \\
\hline & & tomato & Ankara & Kepenekci and Ökten (1996) \\
\hline & & pear & Ankara & Evlice and Ökten (2008) \\
\hline & & apple & $\begin{array}{l}\text { Burdur, } \\
\text { Isparta }\end{array}$ & Kepenekci and Zeki (2002) \\
\hline & & walnut & Bingöl & In this study \\
\hline & \multirow{3}{*}{ H. striatus } & tobacco & Samsun, Sinop & Kepenekci and Ökten (1999) \\
\hline & & chestnut & Sinop, Giresun & Kepenekci (2001) \\
\hline & & walnut & Bingöl & In this study \\
\hline & \multirow{9}{*}{ H. tunisiensis } & tomato & Ankara & Kepenekci and Okten (1996) \\
\hline & & chickpea & $\begin{array}{l}\text { Ankara, } \\
\text { Yozgat }\end{array}$ & Kepenekci (1999) \\
\hline & & bean & Burdur & Kepenekci (1999) \\
\hline & & lentil & Yozgat & Kepenekci (1999) \\
\hline & & kidney bean & Isparta & Kepenekci (1999) \\
\hline & & walnut & Ordu & Kepenekci (2001) \\
\hline & & $\begin{array}{l}\text { eggplant, } \\
\text { grapevine, } \\
\text { pepper, } \\
\text { tomato }\end{array}$ & Diyarbakır & İmren (2007) \\
\hline & & pear & Ankara & Evlice and Ökten (2008) \\
\hline & & walnut & Bingöl & In this study \\
\hline & \multirow[t]{4}{*}{ H. vulgaris } & pear & Ankara & Evlice and Ökten (2008) \\
\hline & & walnut & Bingöl & In this study \\
\hline & & bean & Erzurum & Yüksel (1977) \\
\hline & & $\begin{array}{l}\text { eggplant, } \\
\text { grapevine, } \\
\text { pepper, }\end{array}$ & Diyarbakır & İmren (2007) \\
\hline
\end{tabular}




\section{Pratylenchoides alkani}

Pratylenchid

ae tomato

cotton, Şanlıurfa Yıldız (2007)

unidentified

grass, wheat

$\begin{array}{lll}\text { wheat } & \text { Mardin } & \text { Kılıc (2011) }\end{array}$

barley, melon, Adıyaman

watermelon,

Kasapoğlu Uludamar et al.

wheat,

tobacco

\begin{tabular}{lll}
\hline tomato & Ankara & Kepenekci and Ökten (1997b) \\
\hline pear & Ankara & Evlice and Ökten (2008) \\
\hline
\end{tabular}

$\begin{array}{lll}\text { apple, walnut } & \text { Bingöl } & \text { In this study }\end{array}$

kiwifruit $\quad$ East Black Sea Kepenekci and Öztürk (1999)

P. camachoi

Region

walnut Bingöl In this study

\begin{tabular}{lll} 
mulberry & Erzurum & Yüksel (1977) \\
\hline chickpea & Mardin & Di vito et al. (1994) \\
\hline unidentified grass, & Şanlıurfa & Yıldız (2007)
\end{tabular}

wheat

grapevine $\quad$ Diyarbakır $\quad$ İmren (2007)

plum Antalya Burdur Kepenekci et al. (2001)

P. erzurumensis

Isparta Trabzon

Zonguldak

\begin{tabular}{lll}
\hline olive & Trabzon & Kepenekci (2001) \\
\hline apple & Burdur Isparta & Kepenekci and Zeki (2002) \\
\hline
\end{tabular}

\begin{tabular}{lll}
\hline forage crops & Bingöl & Yildiz et al. (2012) \\
\hline
\end{tabular}

walnut Bingöl $\quad$ In this study

chickpea, lentil $\quad$ Diyarbakir $\quad$ Di vito et al. (1994)

chickpea Mardin Şanlıurfa Di vito et al. (1994)

P. leiocauda

tomato

Ankara

Kepenekci and Ökten (1997b)

\begin{tabular}{lll}
\hline pear & Ankara & Evlice and Ökten (2008) \\
\hline walnut & Bingöl & In this study
\end{tabular}

bean Ankara Karaman Kepenekci (1999)

Yozgat

P. ritteri

Pratylenchidae

Pratylenchus
penetrans

P. thornei

\begin{tabular}{l}
\hline apple \\
\hline walnut \\
\hline walnut \\
eggplant, \\
grapevine, pepper, \\
tomato, wheat
\end{tabular}

Burdur Isparta Kepenekci and Zeki (2002)

Ordu Kepenekci (2001)

Bingöl In this study

Diyarbakır İmren (2007)

tomato, wheat

chickpea, lentil Diyarbakır $\quad$ Di vito et al. (1994)

corn, lentil, Şanlıurfa Ylldız (2007)

unidentified grass

\begin{tabular}{|c|c|c|}
\hline pear & Ankara & Evlice and Ökten (2008) \\
\hline walnut & Bingöl & In this study \\
\hline wheat & Diyarbakır & İmren (2007) \\
\hline chickpea, lentil & DiyarbakırMardin & Di vito et al. (1994) \\
\hline $\begin{array}{l}\text { barley, cotton, } \\
\text { unidentified grass, } \\
\text { wheat }\end{array}$ & Şanlıurfa & Ylldız (2007) \\
\hline wheat & Mardin & Kılıç (2011) \\
\hline $\begin{array}{l}\text { cotton, grapevine, } \\
\text { melon, tobacco, } \\
\text { watermelon, wheat }\end{array}$ & Adıyaman & $\begin{array}{l}\text { Kasapoğlu Uludamar et } \\
\text { al.(2018) }\end{array}$ \\
\hline forage crops & Bingöl & Yıldız et al. (2012) \\
\hline
\end{tabular}




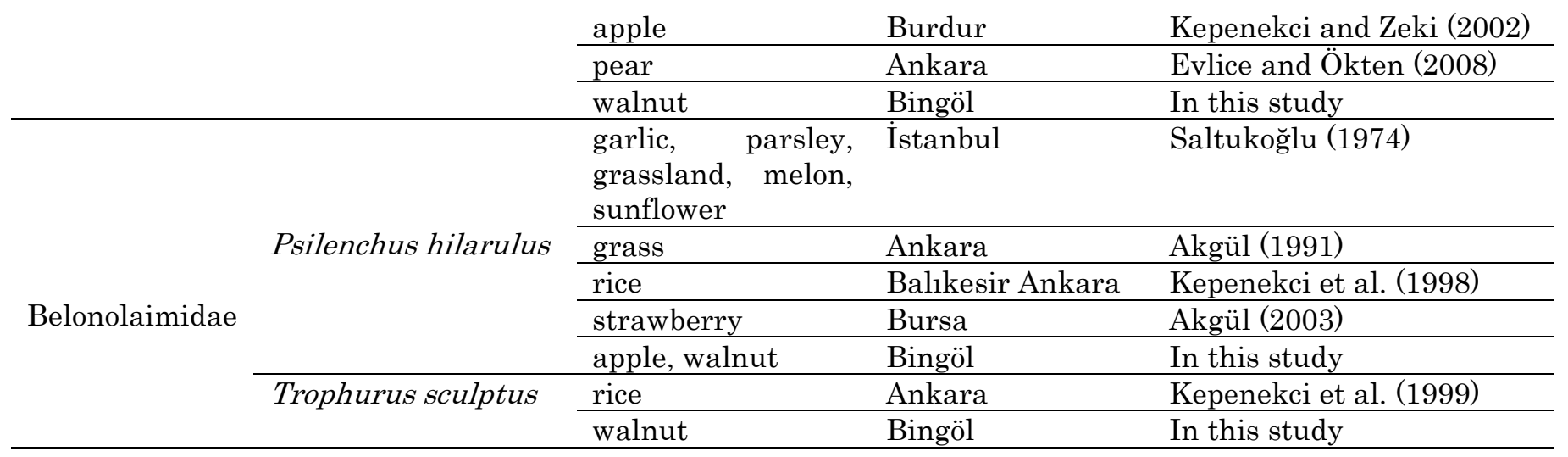

It can be concluded that, PPN fauna of apple and walnut orchards in Bingöl province was revealed for the first time by this study. Therefore, these first record of nematoda fauna of apple and walnut orchards could be the good source of future nematological studies. Due to relatively difficult management strategies of nematodes, the detection of these parasites in the region is becoming very important for developing new and proper control methods/tactics. In order to minimize the nematode damage, cultural practices such as developing resistant varieties, using tolerant grafted seedlings, and etc. should be applied. In addition to these applications, attentions should be paid to internal quarantine measures to prevent dissemination of plant parasitic nematodes to clean areas.

\section{ACKNOWLEDGEMENTS}

This work is part of the master thesis accepted by Kahramanmaras Sutcu Imam University, Institute of Science (Kahramanmaras, Turkey) and was supported by the Republic of Turkey Ministry of Agriculture and Forestry (Project number: TAGEM-BS-14/08-05/0118).

\section{Statement of Conflict of Interest}

Authors have declared no conflict of interest.

\section{Author's Contributions}

The contribution of the authors is equal.

\section{REFERENCES}

Ağaoğlu YS, Çelik H, Çelik M, Fidan Y, Gülşen Y, Günay A, Halloran N, Köksal Aİ, Yanmaz R 1997. Genel Bahçe Bitkileri. T.C. A.Ü.Z.F. Eğitim, Araştırma ve Geliştirme Vakfı Yayınları, No: 4, Ankara.

Akgül HC 1991. Çankaya (Ankara) İlçesindeki Bazı Çim Alanlarında Bulunan Tylenchida Takımına Ait Bitki Paraziti Nematod Türleri Üzerinde Taksonomik Araştırmalar- Taxonomic Studies on the Tylenchida (Nematoda) Species in Grass Areas of Çankaya Region (Ankara). Ankara Üniversitesi
Fen Bilimleri Enstitüsü, Bitki Koruma Ana Bilim Dalı Yüksek Lisans Tezi, 155 sy.

Akgül HC 2003. Plant Parasitic Nematode Species Found in Strawberry Fields in Bursa Region, Turkey. International Journal of Nematology, 13 (2): 215-218.

Barker KR 1985. Nematode Extraction and Bioassays. In: An Advanced Treatise on Meloidogyne, 2 Methodology. (Eds.: K.R. Barker, C.C. Carter and J.N. Sasser). North Carolina State University Grafics,19-39 pp.

Di Vito M, Greco N, Oreste G, Saxena MC, Singh KB, Küsmenoğlu I 1994. Plant Parasitic Nematodes of Legumes in Turkey. Nematologia Mediterranea, 22: 245-251.

Evlice E, Okten ME 2008. Plant Parasitic Nematodes of Tylenchida (Nematoda) Associated with Pear (Pyrus communis L.) Orchards in Ankara District. Bitki Koruma Bulteni, 48: 1-8.

Hooper DJ 1986. Extraction of Free Living Stages from Soil. In: Southey, J. F. (ed.). Labarotory Methods for Work with Plant and Soil Nematodes. Her Majesty's Stationery Office, London: 5-30.

İmren M 2007. Diyarbakır İli Buğday, Sebze ve Bağ Alanlarmnda Önemli Bitki Paraziti Nematod Türlerinin Belirlenmesi. Cukurova Üniversitesi, Fen Bilimleri Enstitüsü, Bitki Koruma Ana Bilim Dalı, Yüksek Lisans Tezi, Adana, 116 sy.

Kasapoğlu Uludamar EB, Yıldız Ş, Imren M, Öcal A, Elekçioğlu İH 2018. Occurrence of Plant Parasitic Nematode Species in Important Crops in the Southeast Anatolia Region of Turkey. Türkiye Entomoloji Dergisi, 42 (1): 63-74.

Kepenekci İ 1994. Beypazarı (Ankara) İlçesinde Havuç (Daucus carota L.) ile Münavebeye Giren Domates (Lycopersicum esculentum Mill.) Ekim Alanlarındaki Tylenchida (Nematoda) Türleri Üzerinde Taksonomik Araştırmalar. Ankara Üniversitesi Fen Bilimleri Enstitüsü Bitki Koruma Ana Bilim Dalı Yüksek Lisans Tezi, Ankara.

Kepenekci İ, Ökten ME 1996. Beypazarı (Ankara) İlçesinde Havuç ile Münavebeye Giren Domates Ekiliş Alanlarında Saptanan Helicotylenchus (Tylenchida, Hoplolaimidae) Cinsine Bağlı Türler. 
Türkiye Entomoloji Dergisi, 20 (2): 137-148.

Kepenekci İ, Ökten ME 1997a. Beypazarı (Ankara) İlçesinde Havuç ile Münavebeye Giren Domates Ekiliş Alanlarında Saptanan Nematod Türleri IV. Coslenchus (Nemata: Tylenchidae) ve Safianema (Nemata: Anguinidae). Bitki Koruma Bülteni, 37 (3-4): 91-99.

Kepenekci İ, Ökten ME 1997b. Beypazarı (Ankara) ilçesinde Havuç ile Münavebeye Giren Domates Ekiliş Alanlarında Saptanan Nematod Türleri III. Pratylenchoides (Nemata: Pratylenchidae). Bitki Koruma Bülteni, 37 (1-2): 1-10.

Kepenekci İ, Ökten ME 1998. Beypazarı (Ankara) ilçesinde Havuç ile Münavebeye Giren Domates Ekiliş Alanlarında Saptanan Nematod Türleri V. Filenchus (Nemata: Tylenchidae). Bitki Koruma Bülteni, 38 (1-2): 1-12.

Kepenekci İ, Ökten ME, Öztürk G 1998. Gönen (Balıkesir) ve Kızılcahaman (Ankara) İlçeleri'ndeki Çeltik (Oryza sativa L.) Ekiliş Alanlarındaki Tylenchida (Nematoda) Takımına ait Bitki Paraziti Nematodlar. Turkiye VIII. Fitopatoloji Kongresi, 21-25 Eylül 1998, Ankara, s: 255-259.

Kepenekci I, Öztürk G 1999. Doğu Karadeniz Bölgesi'nde Kivi (Actinidia deliciosa cv. Hayward) Bahçelerinde Saptanan Tylenchida (Nematoda) Takımına ait Bitki Paraziti Nematodlar. Türkiye III. Ulusal Bahçe Bitkileri Kongresi, 14-17 Eylül 1999, s: 892-896.

Kepenekci İ 1999. Orta Anadolu Bölgesi'nde Yemeklik Baklagil Ekiliş Alanlarındaki Tylenchida (Nematoda) Türleri Üzerinde Taksonomik Araştırmalar. Ankara Üniversitesi Fen Bilimleri Enstitüsü Bitki Koruma Ana Bilim Dalı Doktora Tezi, 270 sy.

Kepenekci İ, Ökten ME 1999. Gerze (Sinop) ve Yakakent, Bafra (Samsun) İlçelerindeki Tütün (Nicotiana tabacum) Ekiliş Alanlarında Saptanan Tylenchida (Nematoda) Takımına ait Bitki Paraziti Nematodlar. Karadeniz Bölgesi Tarım Sempozyumu, 4-5 Ocak 1999, Samsun, s.639-647.

Kepenekci I, Öztürk G, Ökten ME 1999. Two New Species Belonging to Dolichodoroidea Superfamily for the Turkish Nematoda Fauna: Trophurus sculptus Loof, 1956, Scutylenchus tessellatus (Goodey, 1952) Siddiqi, 1979 and Common Species of the Same Superfamily. Journal of Turkish Phytopathology, 28 (1/2): 11-23.

Kepenekci I 2001. Preliminary List of Tylenchida
(Nematoda) Associated with Olive in the Black Sea and the Mediterranean Regions of Turkey. Nematologia Mediterranea, 29 (2): 145-147.

Kepenekci İ, Öztürk G, Akgül HC 2001. Karadeniz ve Akdeniz Bölgelerinde Erik (Prunus domestica L.) Bahçelerinde Saptanan Tylenchida (Nematoda) Takımına ait Bitki Paraziti Nematodlar. Türkiye I. Sert Çekirdekli Meyveler Sempozyumu, 25-28 Eylül 2001, Yalova, s; 519-528.

Kepenekci İ, Zeki C 2002. Nematodes of Tylenchida (Nematoda) Associated with Apple in Turkey. Pakistan Journal of Nematology, 20 (1): 61-63.

Kepenekci I 2014. Plant Parasitic Nematodes (Tylenchida, Nematoda) in Turkey. Pakistan Journal of Nematology, 32 (1): 11-31.

Kılıç M 2011. Mardin İli Buğday Ekiliş Alanlarında Bulunan Bitki Paraziti Nematod Türleri Üzerinde Taksonomik Araştırmalar. Harran Üniversitesi Fen Bilimleri Enstitüsü, Bitki Koruma Ana Bilim Dalı Yüksek Lisans Tezi, 80 sy.

Saltukoğlu ME 1974. A Taxonomical and Morphological Study of Tylenchida (Nematoda) from the Istanbul Area (Turkey)-. A thesis submitted in partial fulfilment of the requirements for the degree of Doctor in Sciences (Zoology) of the State University of Ghent, Belgium. 89 pp.

Seinhorst JW 1959. A Rapid Method for the Transfer of Nematodes from Fixative to Anhydrous Glycerin. Nematologica, 4: 67-69.

Sen SM 1986. Ceviz Yetistiriciliği. Eser Matbaası, Samsun, pp 109-229.

Siddiqi MR 2000. Tylenchida Parasites of Plants and Insects. CABI Publishing, UK, 848 pp.

Southey JF 1986. Principles of Sampling for Nematodes. In: (Southey, J. F. Eds.) Laboratory Methods for Work with Plant and Soil Nematodes. Her Majesty's Stationery Office, London. pp. 1-4.

Yıldız Ş 2007. Şanlıurfa İlinde Nematod Faunası ve Biyoçeşitliliği Üzerine Araştırmalar. Çukurova Üniversitesi, Fen Bilimleri Enstitüsü, Bitki Koruma Ana Bilim Dalı, Doktora Tezi, 102 sy.

Yıldız Ş, Handoo ZA, Carta LK, Skantar AM, Chitwood DJ 2012. A Survey of Plant Parasitic Nematodes Associated with Forage Crops in Bingol, Turkey. Nematologia Mediterranea, 40: 73-77.

Yüksel HŞ 1977. Pratylenchoides alkani n. sp. and $P$. erzurumensis $\mathrm{n}$. sp. (Nematoda: Tylenchoidea) from Soil in Turkey. Proceedings of the Helminthological Society of Washington,.44 (2): 185-188. 